\title{
METACOGNITIVE ANALYSIS OF ELEMENTARY SCHOOL STUDENTS
}

\author{
Ari Metalin Ika Puspita \\ Pendidikan Guru Sekolah Dasar, STKIP PGRI Trenggalek, Indonesia \\ arimetalinikapuspita@stkippgritrenggalek.ac.id
}

Citation: Puspita, A. M. I. (2020). Metacognitive analysis of elementary school students. Indonesian Journal of Elementary Teachers Education, 1 (1), 1-8.

Received: 02-18-2020 Accepted: 05-08-2020 Published: 05-31-2020

\section{ABSTRACT}

This study aims was to investigate the metacognitive abilities of elementary school students. The subjects of this study were elementary school students and teachers from two districts namely Tulungagung and Trenggalek Regencies who had diverse scientific abilities. The data were collected through a questionnaires, semi-structured interviews, and documentation. The data were analyzed through several steps: data collection, data refinement, data processing, data analysis, data analysis process, and conclusions of research results. The results of the study are the aspects of strategic knowledge that is the problems found in schools based on learning strategies that are often done by students, namely repetition. In the aspect of task knowledge it was found that students did not use the right learning strategies with the assignments given by the teacher. While the students' selfknowledge, students have different characteristics. There are students who excel in the academic and non-academic fields. So that each student has advantages and disadvantages both mastery of learning material and outside of learning. This causes differences in achievement for each student.

Keywords: elementary school students; metacognitive. 


\section{INTRODUCTION}

Education is very important for humans because through education humans become more focused and understand the moral values that apply in their environment. Through education, humans will be easy to socialize in their environment. According to Puspita (2019) Improving human resources quality is determined by the quality of education which is getting better in accordance with learning objectives. Social Interaction that is intertwined through interaction and communication will create harmony in social life. Education is a conscious effort planned by developing the potential possessed by students in order to achieve educational goals. The purpose of learning is to improve student competence.

The development of student competencies is very important and urgent in creating quality learning. According to Puspita (2018), learning can be of quality if all the material delivered is able to change the attitudes, thoughts, and knowledge of students from previously not knowing to know and not understanding to understand. But the reality on the ground, several elementary schools found several problems including the way teachers teach in the classroom are still teacher-centered. In addition, it can be seen from the Lesson Plan made by the teacher still using the teacher-dominated learning method, students are just as resistant. Observations carried out in two elementary schools in Tulungagung and Trenggalek Regencies found several problems, namely the Science subject is one of the subjects in primary schools which is considered frightening for most students because it is considered a subject that is difficult for students to understand, other than that according to students' opinions Science subjects consist of subjects that require understanding by memorizing formulas and properties of substances both physical and chemical, which are considered very difficult. So that students' understanding of scientific literacy is very low which results in low learning outcomes. This contrasts with the concept of learning in the 21st Century.

Good learning in the 21 st Century is learning where the teacher facilitates student activities in developing his competence so that he has life skills for his life and independent life. Mukhadis (2013) explains that the 21st Century is a period of knowledge (age), in this era, all alternative efforts to meet the needs of life in a variety of contexts are more knowledge-based and increased literacy, especially scientific literacy. According to Puspita (2019) Science literacy, a person who is scientific literacy will make someone think based on scientific concepts, have scientific abilities, and be able to make conclusions based on empirical facts that have been studied previously. So it needs to be applied innovation in learning so that student competencies in learning science can be optimal.

Competencies that must be mastered by students according to Suherman (2014) include: (1) the first cognitive abilities consisting of understanding, reasoning, application, analysis, observation, identification, investigation, exploration, connection, communication, inquiry, hypothesis, conjecture, generalization, creativity, solving problems; (2) the second affective abilities consisting of self-control which includes self-awareness, mood management, impulse control, positive activity motivation, empathy; and (3) the third psychomotor abilities consisting of socialization and personality which include the ability of argumentation, presentation, behavior. Based on contemporary psychology, Goldman (1995) mentions competencies related to academic abilities, especially cognitive has a major contribution to individual development. Based on this, it seems that the metacognitive abilities of students are very important to be developed early.

Metacognitive can be classified in high cognitive abilities because it contains elements of analysis, synthesis, and evaluation as the embryo of the growth and development of inquiry and creativity abilities. Therefore the implementation of learning should accustom students to practice metacognitive abilities through various experiences that require students 
to be active, innovative, creative, and fun so that metacognitive develop well without any element of coercion. Metacognitive has become one of the elements of assessment in the 2013 curriculum that applies in primary schools in Indonesia today.

In the 2013 Curriculum, there are forms or dimensions of knowledge including factual, conceptual, procedural, and metacognitive. On this metacognition dimension in the learning process students involve thinking about the thought process for example learning skills, memory skills, and the ability to monitor learning. Metacognitive dimensions possessed by students are expected students to have an independent attitude and know what is being and has been learned and what must be learned.

\section{RESEARCH METHOD}

\section{Research Design}

This type of research used in this research is case study research, where the understanding of case study research is a research method that specifically investigates contemporary phenomena (objects in progress or has taken place but still leaves a broad, strong or special impact and influence at the time the research is conducted ) that is in a reallife context, using various data sources. Type of case study research entered as one type in qualitative research methods. Qualitative method is a research method used to examine the condition of natural objects, where researchers as a key instrument, data collection techniques are carried out by triangulation (combined), data analysis is inductive and the results of research emphasize the meaning (Sugiyono, 2008).

\section{Data Collection}

In qualitative research, the data source is selected by means of purposive sampling, which is chosen with specific considerations and objectives (Sugiyono, 2008). The research sample is 52 students and 2 elementary school teachers from 2 schools in two different cities namely Tulungagung and Trenggalek Regencies. The selection of research samples is based on several categories namely the level of students' understanding of science varies and has implemented the 2013 Curriculum. Data collection techniques are by means of observation, interviews, and documentation. The instruments used in this study were observation and interview guides.

\section{Data Analysis}

The data analysis techniques in this study are (1) data collection, (2) data refinement, (3) data processing, (4) data analysis, (5) data analysis process, and (6) conclusions of research results.

\section{RESULTS AND DISCUSSION}

The results of research on elementary school students grade IV SDN I Campurdarat and SDN I Surodakan can be said to be good. Indicators used to measure metacognitive that students have a good level of knowledge include three aspects of learning metacognitive knowledge, namely aspects of strategic knowledge, aspects of task knowledge, and aspects of self-knowledge. First, in this aspect of knowledge of strategies, a number of things can be done, namely planning, monitoring, and monitoring. With Strategy Knowledge, a person knows which metacognitive strategies will be used and when to use them in order to complete a series of tasks. Constraints found in schools are based on general learning strategies which include repetition, strategies, and elaboration, from the three strategies above that are often carried out by students, namely repetition. The reason students use the 
repetition strategy because this strategy is easy to apply in the learning process and is a strategy that is very often used by teachers. The teacher assumes that students cannot master other strategies that are more varied, so the teacher only uses one strategy in the learning process and there is no effort to train students in using other strategies in a sustainable manner. Students use strategies with the aim of making students able to focus when students explore new information or knowledge. However, when students experience difficulties in understanding information or knowledge, students ask for help from teachers or students repeat reading knowledge that is considered difficult. In this way, students can solve problems found during learning based on the activities that students do. So that the support of the teacher when the activity asks and stimulates students to focus on learning, students will have the ability to set learning strategies.

Secondly, in the aspect of task knowledge, it was found that: (1) students did not use the right learning strategy with the assignment given by the teacher. In the learning process, students only apply one learning strategy that students often use and are considered easy. Then in assigning both the process and the end of the pursuit of the type of task given to students is less varied and has not been able to measure the student's final ability; and (2) During the learning process there are striking differences in the preparation and learning process between male and female students. Male students do not have the initial knowledge to prepare for learning, lack of discipline during the learning process, the completion of tasks given to students is not on time given and the initial preparation is not optimal due to lack of motivation given to students. Whereas the female students had good initial knowledge so that during the learning process girls were able to follow the material well provided by the teacher, the timeliness of completing the assignment was in accordance with the time given, the discipline to follow and complete the assignments was quite good, and the initial preparation of learning was better than a male student.

Third, in students' self-knowledge, students have different characteristics. There are students who excel in the academic and non-academic fields. So that each student has advantages and disadvantages both mastery of learning material and outside of learning. This causes differences in achievement for each student.

Based on the results and findings of research in class IV at SDN 1 Campurdarat Tulungagung Regency and SDN 1 Surodakan in Trenggalek Regency, it was explained that metacognitive knowledge of grade IV students at two elementary schools in the 11-year age range is said to be quite good. This is in accordance with Ozsoy et al., (2009) and García et al., (2015) state that in children with an average age of 11 years the level of metacognitive knowledge is at a moderate level. The situation is normal because the development process will continue in line with the age of the child (Schneider and Lockl, 2002). So it can be concluded that the more a child rises his grade level, the better the metacognition. Because metacognition requires the ability to think and analyze high levels, so children who have a good level of metacognition are in the high class of ages 11 to 13 years.

Metacognition as a form of cognition, or two or more levels of thought processes that involve control of cognitive activity. Therefore, metacognition can be said as someone's thinking about one's own thinking or one's cognition about one's own cognition. According to Flavel (in Jonassen, 2000) metacognitive that is one's awareness of how to learn, the ability to assess the difficulty of a problem, the ability to observe the level of understanding of himself, the ability to use various information to achieve goals, and the ability to assess the progress of learning themselves. Metacognitive activities ask students to reflect on what they know, what they care about and what they can do not only help students build self-awareness, but also provide valuable information for teachers (Darling-Hammond, Austin, Cheung, and 
Martin, 2003). Pintrich \& Schunk (2002) restarts a general framework of metacognition into three categories by including students' knowledge of general strategies for learning and thinking (knowledge of strategies) and their knowledge for cognitive tasks and when and why to use different strategies (knowledge of cognitive tasks, including appropriate contextual and conditional knowledge). One aspect of learning metacognitive knowledge, namely aspects of strategic knowledge.

Strategy knowledge according to Pintrich \& Schunk (2002) is knowledge of general strategies for learning, thinking, and solving problems. This strategy can be applied to all or most disciplines or domains of subject matter in contrast to strategies that are more specific from the discipline or domain. Strategic knowledge can be used in a large number of different tasks and domains, more useful for one particular type of task in one particular subject. Metacognitive strategies help students be more efficient and have more power in learning because metacognitive strategies help students find information, assess when students need additional material resources, and understand when to apply different approaches to a problem found when students learn (Darling-Hammond et. al, 2003). In addition to knowledge, knowledge of metacognitive strategies, namely task knowledge.

Knowledge of cognitive tasks explains that different learning tasks can be said to be difficult, can also be said to be less difficult by certain students according to students' cognitive abilities and learning situations. This can happen because different tasks may require different cognitive strategies. For example, a task of recalling is more difficult than the task of recognizing a voice, for example, because in a task of recalling, individuals must actively search for memory and retrieve relevant information, whereas, in the task of recognizing sounds, the emphasis is on discriminating between alternatives and choosing answers appropriate (Pintrich \& Schunk, 2002). The next metacognitive knowledge is selfknowledge.

Self-knowledge according to Flavell (Pintrich \& Schunk, 2002) is an important component in metacognitive knowledge. This self-knowledge includes knowledge of one's strengths and weaknesses. In addition to general self-knowledge, individuals also have beliefs about their motivations (Pintrich \& Schunk, 2002). Although motivational beliefs are not usually considered in cognitive models, there is a considerable body of literature that appears to show important relationships between students' motivational beliefs, cognition and student learning (Pintrich \& Schrauben, 1992; Pintrich \& Schunk, 2002). It seems important that just as students need to develop self-knowledge and self-awareness about their knowledge and cognition, they also need to develop self-knowledge and self-awareness about their motivation.

\section{CONCLUSION AND RECOMMENDATION}

Students have a good level of knowledge covering three aspects of learning metacognitive knowledge, namely aspects of strategic knowledge, aspects of task knowledge, and aspects of self-knowledge. In the aspect of knowledge strategy, students use a repetition strategy because this strategy is easily applied in the learning process and is a strategy that is very often used by teachers. In the aspect of task knowledge, students do not use the right strategy in completing the assignment and there are differences in the readiness of learning and students' initial knowledge between male and female students. Aspects of selfknowledge, students have different characteristics. So that each student has advantages and disadvantages both mastery of learning material and outside of learning. This causes differences in achievement for each student. The focus of the 2013 curriculum, one of which is on the metacognitive dimension, aims to make students have independence, high-level 
thinking skills, and analyze a problem based on facts found in the field so that the knowledge obtained by students is systematically structured and structured and lasts long.

Teachers in the management of learning are expected to pay attention to the development of students' metacognitive knowledge. The teacher designs interesting learning and implements varied learning strategies so as to be able to improve students' metacognitive abilities and knowledge. The results of this study can be used as a scientific discourse for other researchers to conduct research that is broader and deeper and able to be a reference in improving the metacognitive students in elementary schools. 


\section{REFERENCES}

Darling-Hammond, Linda, Austin, K., Cheung, M., \& Martin, D. (2003). Thinking about thinking: metacognition. Stanford: Stanford University School of Education.

Flavell, J. H. (1979). Metacognition and cognitive monitoring: A new area of cognitivedevelopmental inquiry. American Psychologist, 34 (10), 906-911.

García, T., Cueli, M., Rodríguez, C., Krawec, J. \& Castro, P. G. 2015. Metacognitive knowledge and skills in students with deep approach to learning. Evidence from mathematical problem solving. Revista de Psicodidáctica, 20 (2), 209-225.

Goldman, D. (1995). Emotional intelligence. New York: Bantam Books.

Jonassen, D. H. (2000). Toward a design theory of problem solving to appear in educational technologi: research and depelopement. ETR\&D, 48, 63-85.

Mukhadis, A. (2013). Sosok manusia indonesia unggul dan berkarakter dalam bidang teknologi sebagai tuntutan hidup di era globalisasi. Jurnal Pendidikan Karakter, 3 (2), 115-136. Retrieved from https://journal.uny.ac.id/index.php/jpka/article/view/1434/1222.

Ozsoy, G., Memis, A., \& Temur, T. (2009). Metacognition, study habits and attitudes. International Electronic Journal of Elementary Education, 2 (1), 154-166.

Pintrich, P. R., \& Schrauben, B. (1992). Student's motivational beliefs and their cognitive engagement in classroom academic task. In D. Schunk \& J. Meece (Eds.), Student Perception in the Classroom; Causes and Consequences. New Jersey: Lawrence Erlbaum.

Pintrich, P. R., \& Schunk, D. H. (2002). Motivation in education: theory, research, and applications 2nd ed. New Jersey: Merril Prentice Hall.

Puspita. A. M. I. (2019). Peran budaya literasi pada peningkatan karakter siswa sekolah dasar. Pedagogia: Jurnal Pendidikan, 8 (1), 105-113.

Puspita, A. M. I. (2019). Efektivitas pendekatan kontekstual untuk meningkatkan keterampilan literasi sains siswa sekolah dasar. Eduproxima. Jurnal Ilmiah Pendidikan IPA, 1 (1), 1-8.

Puspita, A. M. I. (2018). Pengaruh bahan ajar tematik berbasis kontekstual terhadap aktivitas belajar siswa. Jurnal Inovasi Pendidikan, 3 (2), 47-52.

Schneider, E. \& Lockl, K. 2002. The development of metacognitive knowledge in children and adolescents. In Perfect, J. T., \& Scwartz, B. L. (Eds), Applied Metacognition. United Kingdom: Cambridge University Press. 
Sugiyono. (2008). Metode penelitian kunatitatif, kualitatif, dan $r \& d$. Bandung: Alfabeta.

Suherman, E. (2014). Kompetensi yang harus dimiliki siswa. Jurnal Pendidikan dan Budaya. 5 (2). 